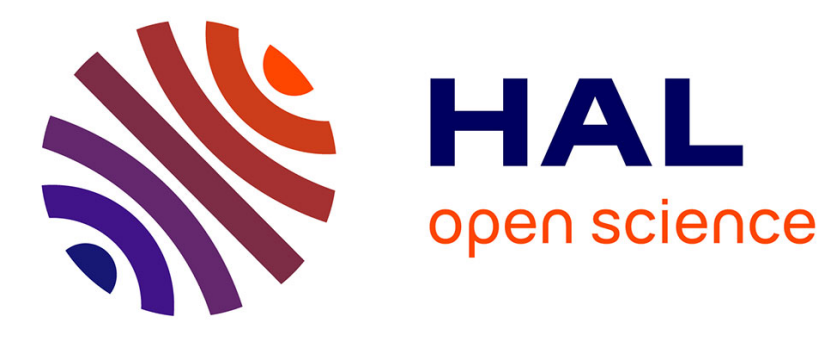

\title{
Mammary blood flow and nutrient uptake
}

Chantal Farmer, N.L. Trottier, Jean-Yves Dourmad

\section{To cite this version:}

Chantal Farmer, N.L. Trottier, Jean-Yves Dourmad. Mammary blood flow and nutrient uptake. The gestating and lactating sow, Wageningen Academic Publishers, 2015, 978-90-8686-253-5. 10.3920/978-

90-8686-803-2_14. hal-01210733

\section{HAL Id: hal-01210733 \\ https://hal.science/hal-01210733}

Submitted on 5 Jun 2020

HAL is a multi-disciplinary open access archive for the deposit and dissemination of scientific research documents, whether they are published or not. The documents may come from teaching and research institutions in France or abroad, or from public or private research centers.
L'archive ouverte pluridisciplinaire HAL, est destinée au dépôt et à la diffusion de documents scientifiques de niveau recherche, publiés ou non, émanant des établissements d'enseignement et de recherche français ou étrangers, des laboratoires publics ou privés. 


\title{
14. Mammary blood flow and nutrient uptake
}

\author{
C. Farmer ${ }^{*}$, N.L. Trottier ${ }^{2}$ and J.Y. Dourmad ${ }^{3}$ \\ ${ }^{1}$ Agriculture and Agri-Food Canada, Dairy and Swine R \& D Centre, 2000 College St., \\ Sherbrooke, QC, J1M 0C8, Canada; chantal.farmer@agr.gc.ca \\ ${ }^{2}$ Michigan State University, Department of Animal Science, 2209 Anthony Hall, East \\ Lansing, MI 48824, USA \\ ${ }^{3}$ INRA-Agrocampus Ouest, UMR1348 PEGASE, 35590 Saint-Gilles, France
}

\begin{abstract}
Sow milk is the major source of nutrients for suckling piglets and taking into account the large litter sizes of our current sow genotypes, it is imperative to maximize nutrient use by the mammary gland. The amount of nutrients available to mammary tissue is dependent upon the concentrations of nutrients in blood and the rate of its flow to the lactating glands. Nutrient availability to the udder may be estimated by measuring mammary arteriovenous differences, and mammary blood flow can be measured either directly or via indirect calculations. For all these measures, mammary venous and arterial blood samplings are required and catheters must be inserted in mammary veins. Blood flow to the udder is influenced by numerous factors, such as litter size, time since feeding, postural behaviour, vasoactive substances, and ambient temperature; yet, the single most important effector of mammary blood flow is milk removal. Glucose represents 40 to $60 \%$ of the total carbon mass taken up by sow mammary tissue and its uptake by the mammary gland appears to be mediated by glucose transporter proteins. Other energetic precursors which are used by the mammary gland are triglycerides, phospholipids, acetate, propionate and lactate. The uptake of amino acids by sow mammary glands has been extensively studied and is affected by diet, stage of lactation, and milk demand. Recent data also showed that amino acid uptake is controlled by transporter proteins that channel amino acids intracellularly, and that these proteins are in turn affected by diet and physiological status. Data on mammary uptake of hormones are contradictory; yet, the endocrine involvement in the regulation of milk synthetic processes is evidenced by the presence of specific hormonal receptors in mammary tissue.
\end{abstract}

Keywords: dietary nutrients, lactation, mammary gland, mammary uptake, sow

\subsection{Introduction}

Sow milk yield is the major determinant of growth of suckling piglets and, in turn, weight of piglets at weaning has a major impact on their post-weaning gain (Klindt, 2003). Yet, primiparous sows cannot produce optimal milk yields because of underdeveloped mammary tissue, low voluntary feed intake during lactation, and their prolonged catabolic state present during late-gestation and lactation (see Chapter 4; Farmer and Hurley, 2015 and Chapter 7; Theil, 2015 from this book). It is therefore imperative to find ways to 
improve sow milk yield and a better understanding of the mechanisms involved in the control of milk production is needed to achieve that goal. Nutrients available to mammary tissue may be enhanced by increasing the concentrations of nutrients in blood and the blood flow to the glands (Renaudeau et al., 2002). The present chapter therefore focusses on mammary blood flow and the uptake of nutrients and hormones by mammary tissue in swine. The direct and indirect methods of estimating blood flow will be described and an update on the current knowledge of the factors involved in its regulation will be provided. Mammary uptake of major nutrients, such as glucose and amino acids, and of other energetic precursors will be covered, with some emphasis on novel findings pertaining to glucose and amino acid transporters. Finally, the limited information available on mammary uptake of hormones will be summarized and the potential involvement of specific hormones for nutrient uptake by the sow's udder discussed.

\subsection{Blood flow}

\subsubsection{Anatomy of the mammary circulatory system}

The arterial, venous and lymphatic circulation of the sow mammary glands are provided on each side of the ventral midline by a network that extends longitudinally from the axillary to the inguinal regions (Schummer et al., 1981), as depicted in Figure 14.1. In contrast to ruminants where only one artery (pudendal artery) supplies blood to both sides of the udder (Barone, 1996), several arteries supply each side of the sow's udder (Trottier et al., 1995a). The external pudendal artery descends through the inguinal canal where it divides into the lateral cranial, middle cranial and medial cranial branches

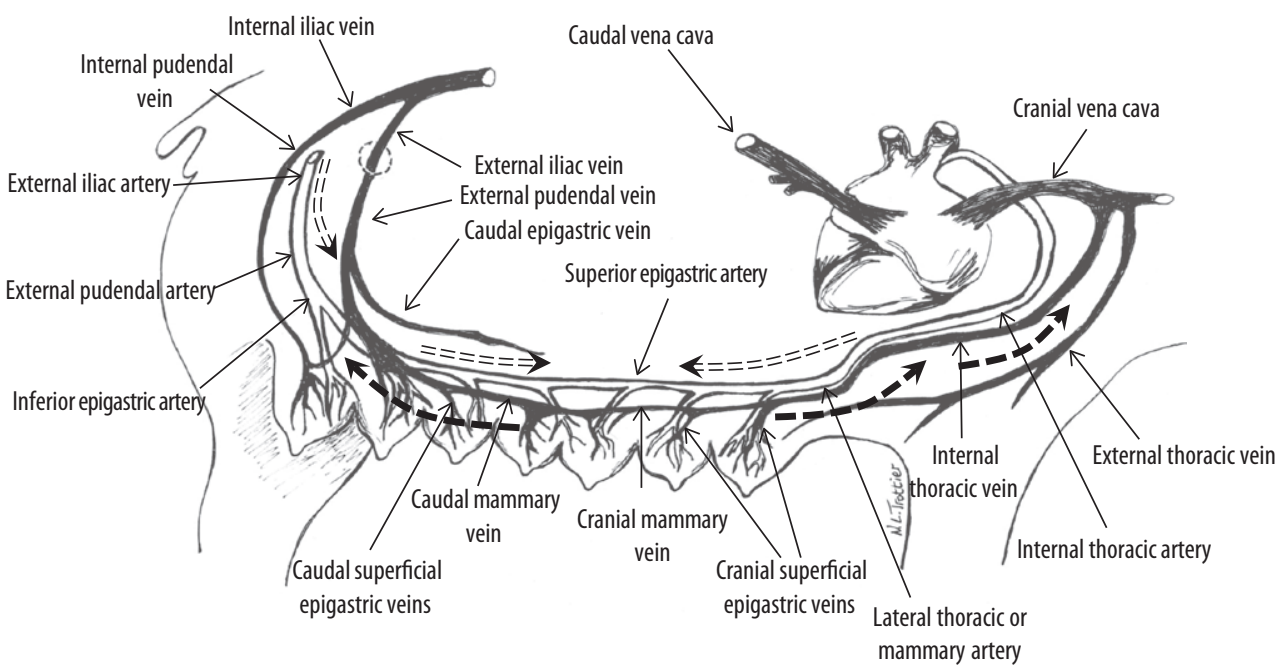

Figure 14.1. Illustration of the lactating sow mammary circulatory system. The oval line represents the inguinal canal. Single dash arrows indicate direction of venous blood flow and double dash arrows indicate direction of arterial blood flow. Arteries are opened and veins are filled. Drawing not to scale. 
supplying the posterior mammary glands (Ghoshal, 1975). The anterior mammary glands are mainly supplied by the cranial epigastric artery originating from the internal thoracic artery (Ghoshal, 1975; Trottier et al., 1995a). Blood leaving the mammary glands uses two distinct pathways (Turner, 1952); the anterior glands are drained cranially through two subcutaneous abdominal veins which run parallel on each side of the mammary system to reach the internal thoracic vein (Trottier et al., 1995a). Blood that exits the posterior glands in the inguinal region does so caudally by way of the same subcutaneous abdominal vein thereby draining into the external pudic vein (Turner, 1952). In contrast to other litter baring species studied to date, superficial veins arising from the mammary parenchyma and branching from the epigastric veins are joined between the right and left side of each pair of glands through venous anastomosis (Lignereux et al., 1996).

\subsubsection{Estimating mammary blood flow}

Mammary venous and arterial blood samplings are required to measure blood flow and to estimate mammary nutrient uptake. Mammary blood flow in lactating sows has been estimated both directly and indirectly. All porcine mammary blood flow values obtained by indirect methods (Guan et al., 2002, 2004a,b; Linzell et al., 1969a; Nielsen et al., 2002a,b; Trottier et al., 1997) are based on Fick's original principle of diffusion (Fick, 1870). Kety and Schmidt (1945) adapted the Fick's principle to measure cerebral blood flow using nitrous oxide as an inert marker. Linzell et al. (1969a) used the KetySchmidt method (Kety and Schmidt, 1945) and DO as an inert marker to estimate blood flow across one single mammary gland. This value was then used to estimate blood flow across the entire udder (Table 14.1). In that same study, Linzell et al. (1969a) also measured for the first time, the arteriovenous difference in nutrient concentrations by sampling mammary venous and arterial blood following catheterization of the external pudic artery and of a mammary vein draining a single functional gland (Figure 14.1). Milk yield of the gland was measured over a 5-h period and total mammary tissue was weighed at the end of the study to allow estimation of milk yield and blood flow per 100 $\mathrm{g}$ of mammary tissue. For the purpose of comparison with other studies, milk yield and blood flow values in this chapter were estimated for an entire udder based on an udder weight of $770 \mathrm{~g}$ (Table 14.1).

When applying the Fick's principle to measure blood flow in lactating sows, catheter placement for the arterial infusion of an external inert marker and blood sampling may be done using any arterial sites. The Fick approach, however, is more feasible for determination of long-term changes in blood flow (i.e. daily) as opposed to changes occurring in the short term (i.e. minutes). More recent studies (Guan et al., 2002, 2004a,b; Manjarín et al., 2012b; Nielsen et al., 2002a,b; Trottier et al., 1997) applied the Fick's principle to estimate mammary blood flow using an internal marker. The advantage of an internal marker is that there is no need for arterial infusion of an external marker. In those studies, lysine or phenylalanine + tyrosine were used with the major premise that lysine and phenylalanine are negligibly catabolized or utilized by the porcine mammary gland, other than their incorporation into milk proteins (Guan et al., 2002, 2004a). Such assumption may however have led to an underestimation of mammary plasma flow. For instance, Lapierre et al. (2009) reported lysine to be utilized and oxidized through pathways for non-milk protein 
Table 14.1. Mammary plasma flow through the entire mammary gland, milk yield and amount of plasma required to produce $1 \mathrm{~kg}$ of milk estimated from data of various studies in sows fed diets providing the minimum nutrient requirements (Farmer et al., 2008b).

\begin{tabular}{llllll}
\hline Study & Method & Litter size & Plasma flow (I/min) & Milk yield (I/d) & Plasma (I per I milk) \\
Guan et al. (2002) & Fick (phe + tyr) & 12 & 4.9 & 12.1 & 581 \\
Guan et al. (2004a) & Fick (lysine) & 11 & 4.5 & 11.4 & 560 \\
Guan et al. (2004b) & Fick (lysine) & 11 & 3.6 & 10.7 & 490 \\
Linzell et al. (1969a) & Fick (3H0) & 6 & $1.9^{3}$ & 6.2 & $441^{3}$ \\
Nielsen et al. (2002b) & Fick (lysine) & 8 & 3.2 & 10 & 550 \\
Nielsen et al. (2002a) & Fick (lysine) & 12 & 5.5 & 7.4 & 1,050 \\
Nielsen et al. (2002a) & Fick (methionine) & 12 & 4.4 & 7.4 & 858 \\
Nielsen et al. (2002a) & Fick (calcium) & 12 & 2.8 & 7.4 & 548 \\
Renaudeau et al. (2002) & Flow probe & 12 & $3.6^{3}$ & 11 & $471^{3}$ \\
Renaudeau et al. (2002) & Fick (lysine) & 12 & $3.9^{4}$ & 11 & 511 \\
Trottier et al. (1997) & Fick (lysine) & 11 & 3.0 & 8.1 & 541 \\
\hline
\end{tabular}

\footnotetext{
${ }^{1}$ Phenylalanine + tyrosine.

${ }^{2} \mathrm{~A}$ weight of $770 \mathrm{~g}$ for the gland subjected to blood flow measurement was derived from the reported milk yield of $43 \mathrm{ml} / \mathrm{h}$ or $134 \mathrm{ml} / \mathrm{d}$ per $100 \mathrm{~g}$ of tissue, and blood flow of $41 \mathrm{ml} / \mathrm{min}$ per $100 \mathrm{~g}$ of tissue. Blood flow through that gland was recalculated as $\mathrm{I} / \mathrm{gland} /$ day where $41 \mathrm{ml} /$ $\mathrm{min} / 100 \mathrm{~g}$ tissue represents $316 \mathrm{ml} / \mathrm{min} / \mathrm{gland}$ or $455 \mathrm{l} / \mathrm{day} / \mathrm{gland}$. The number of functional glands was based on the number of suckling piglets, to calculate mammary blood flow through all functional glands. This value was verified by dividing the total mammary tissue weight of $4.62 \mathrm{~kg}$ by the single gland weight of $770 \mathrm{~g}$ (as estimated above). Thus, total mammary blood flow was estimated as 2,728 $\mathrm{l} / \mathrm{day}$ ( $455 \mathrm{l} \mathrm{l} / \mathrm{day} / \mathrm{gland} \times 6$ glands $)$ and total milk yield as $6.19 \mathrm{l} / \mathrm{day}(1,032 \mathrm{ml} / \mathrm{day} \times 6$ glands). Milk yield per gland was estimated as $1,032 \mathrm{ml} / \mathrm{day}$ where $134 \mathrm{ml} / 100 \mathrm{~g}$ tissue per day $\times 770 \mathrm{~g} / \mathrm{gland}$.

${ }^{3}$ Values are for blood flow and liter of blood per liter of milk.

${ }^{4}$ Estimated from reported blood to milk ratio of 511 and average milk yield of $111 / \mathrm{d}$.
}

synthesis in lactating dairy cows. Also, the NRC (2012) recently estimated dietary lysine efficiency of utilization into milk protein synthesis to be $67 \%$ in sows; albeit this value appears to be overestimated, the findings of Lapierre et al. (2009) in dairy cows together with this NRC (2012) estimate suggest that lysine utilization by the porcine mammary gland may be of greater significance than previously suggested.

Most of the reported plasma flow values from studies using Fick's principle range from 1.9 to $4.9 \mathrm{l} / \mathrm{min}$ with corresponding plasma:milk (vol:vol) and milk yield, respectively ranging from 441 to 581 and 6.2 to $12.1 \mathrm{l} / \mathrm{d}$ (Table 14.1). Plasma:milk values as high as 1,050 and 858 were also reported when lysine and methionine, respectively, were used as internal markers (Nielsen et al., 2002a, Table 14.1). These values raise questions when considering the reported low average daily milk production of $7.4 \mathrm{~kg}$ for a litter size of 12 (Nielsen et al., 2002a). In that same study, when calcium was used as marker, the average plasma flow was $2.8 \mathrm{l} / \mathrm{min}$, a value falling within the reported range. Because no other studies are available to compare the plasma flow estimated with calcium, it is unknown whether calcium is a valid marker. Unlike amino acids, calcium is not metabolized hence 
it offers the advantage of falling under the definition of 'inert' marker. On the other hand, given the low arteriovenous difference and extraction rate of $\mathrm{Ca}$ (Nielsen et al., 2002a) its validity as an internal marker is questionable.

Renaudeau et al. (2002) obtained direct measurements of blood flow through the mammary glands of lactating sows by implanting an ultrasonic blood flow probe around the right external pudic artery. The average pudic mammary blood flow was $910 \pm 283$ $\mathrm{ml} / \mathrm{min}$, corresponding to $3.6 \mathrm{l} / \mathrm{min}$ or $4,984 \mathrm{l} /$ day. These values compare to those obtained from previously-cited authors using the Fick principle (Table 14.1). This approach offers the advantage of evaluating short-term changes (i.e. minutes) in mammary blood flow

\subsubsection{Regulation of mammary blood flow}

Regulation of blood flow to the sow udder and each of the respective mammary glands is poorly understood. One major factor that appears to play a significant role in modulating blood flow is milk removal. Renaudeau et al. (2002) reported that mammary blood flow decreased markedly shortly after intravenous administration of oxytocin in sows and returned to basal values as quickly as $12 \mathrm{~min}$ following initiation of nursing. Thereafter, blood flow increased and reached a maximum value $22 \mathrm{~min}$ after the onset of milking. It was suggested that the post-suckling increase in mammary blood flow may be in response to the nursing event or to the decrease in milk volume. Olsson et al. (2003) showed that a jugular vein infusion of oxytocin caused a short-term increase in mammary blood flow in lactating goats. It was also demonstrated that there is an increase in intra-mammary pressure during natural milk ejection or following an intravenous injection of oxytocin in sows and that the timing of milk ejection between teats may be influenced by blood flow (Kent et al., 2003). The link between nursing and mammary blood flow is also apparent at weaning, whereby blood flow decreases by 40 and 60\%, respectively, 8 and $16 \mathrm{~h}$ after weaning in pigs (Renaudeau et al., 2002). A positive relationship between litter size and mammary plasma flow was reported by Nielsen et al. (2002b); as litter size increased from 3 to 13 , mammary plasma flow increased linearly from approximately 2,000 $1 / \mathrm{d}$ to over 5,000 $\mathrm{l} / \mathrm{d}$, reflecting an increase in the number of functional glands and total milk demand. Minor changes in mammary blood flow in sows are also seen with postural changes and time relative to feeding. Renaudeau et al. (2002) reported a 6\% decrease in mammary blood flow when sows were standing compared with lying, and a 7.7\% increase after a meal reaching a peak 65 min post-prandially. The effect of ambient temperature on mammary blood flow (Renaudeau et al., 2003) was also examined. While exposure of sows to an ambient temperature of $28{ }^{\circ} \mathrm{C}$ did not affect milk yield, mammary blood flow increased by approximately $8 \%$. The authors suggested that this small increase was consequent to an increase in blood flow to subcutaneous capillaries for dissipating heat.

Nitric oxide, also known as the endothelium-derived factor, stimulates vascular smooth muscle relaxation resulting in vasodilation and increase in blood flow. Lacasse et al. (1996) demonstrated that intra-mammary infusion of a nitric oxide donor in lactating goats rapidly increased mammary blood flow. Yet, a causal relationship between mammary blood flow and milk yield remains to be demonstrated. Mammary blood flow of goats was affected unilaterally and milk yield was measured. 
Responses of the milk vein and the cranial mammary artery to potential other vasoactive substances were studied in isolated blood vessels of lactating sows. Noradrenaline, serotonin, prostaglandin F, prostacyclin, histamine and potassium had vasoconstrictive effects on both these vessels whereas acetylcholine had a relaxing effect on both arterial and vein and $\beta$-adenosine had a relaxing effect on the milk vein only (Busk et al., 1999). In rodents and humans, adrenergic nerve fibers cause constriction of blood vessels in the mammary gland thereby reducing blood flow through the glands (Erikson et al., 1996). Franke-Radowiecka and Wasowicz (2002) showed that, in swine, the majority of adrenergic and acetylcholinesterase-positive nerve fibers are localized in the subcutaneous tissue of the nipple and mammary glands. Franke-Radowiecka and Wasowicz (2002) reported that cholinergic innervation is considerably less abundant than adrenergic innervation in porcine mammary glands. Nerve supply to the cranial mammary glands of sows differs from that to the inguinal glands. Cranial mammary glands receive their innervation from thoracic nerves whereas inguinal mammary glands receive their innervation mainly from the pudendal nerve (Klopfenstein et al., 2006).

\subsection{Uptakes of nutrients}

\subsubsection{Measure of mammary arteriovenous difference}

Measurements of mammary nutrient arteriovenous difference (AVD) and uptake necessitate cannulation of an artery and of the major venous system draining the mammary parenchyma. In these in vivo studies, arterial blood was collected following cannulation of the carotid and venous blood following cannulation of the abdominal vein (Trottier et al., 1995a; Figure 14.1). The cranial end of the anterior portion of the mammary system is the preferred cannulation site for representative measurement of nutrient concentrations contributed by glands located in both the thoracic and abdominal regions. In addition, mammary involution appears to be initiated in the inguinal region in smaller litters, whereas the abdominal and thoracic glands usually remain functional until the end of the lactation period (Kim et al., 2001).

\subsubsection{Uptake of glucose}

Blood glucose is the major precursor for the synthesis of lactose. Glucose represents 40 to $60 \%$ of the total carbon mass taken up by sow mammary tissue (Dourmad et al., 2000; Linzell et al., 1969b; Renaudeau et al., 2003; Spincer et al., 1969). Glucose uptake by the mammary gland makes up a considerable proportion of the total body glucose requirement. Once in the mammary gland, glucose is used as the main substrate for lactose, glycerol and fatty acid synthesis (Linzell et al., 1969b) and may also provide energy for metabolic processes associated with maintenance of the mammary gland. Linzell et al. (1969a) reported an extraction rate of glucose by the mammary gland of about $26 \%$. This is consistent with the estimates of 31\% obtained by Spincer et al. (1969) and $26 \%$ by Renaudeau et al. (2003), whereas Dourmad et al. (2000) and Trottier et al. (1995b) reported lower values of 20 and $20.7 \%$, respectively. Using labeled-carbon glucose, Linzell et al. (1969b) estimated that $53 \%$ of glucose was used for lactose synthesis, 
$34 \%$ was oxidized to $\mathrm{CO}$ and the remaining $13 \%$ was used for fatty acid or amino acids synthesis. For instance, Dourmad et al. (2000) showed that free fatty acids AVD decreased to negative values post-feeding during the peak of glucose AVD, indicating that glucose utilization for fatty acid synthesis increases under absorptive state. The same authors also reported lactate AVD to increase post-feeding compared with pre-feeding, indicative of increased glucose oxidation under absorptive state. The mammary gland appears to respond to dietary glucose availability by altering the AVD; in the study by Dourmad et al. (2000), AVD for glucose markedly decreased $16 \mathrm{~h}$ post-prandially from 24.2 . to $12.2 \mathrm{mg} / \mathrm{dl}$, a decrease that was directly related to that of arterial glucose concentrations from 126.8 to $62.4 \mathrm{mg} / \mathrm{dl}$. Albeit based on only one study, given that the extraction rate of glucose by the sow mammary gland remained constant over a relatively wide range of arterial glucose concentrations (i.e. 126.8 to $62.4 \mathrm{mg} / \mathrm{dl}$ ), glucose uptake by the mammary gland is likely mediated by high capacity, low affinity glucose transporter proteins.

Transcript abundance for the genes SLC2A1, SLC2A4, and INSR, respectively encoding for the non-insulin dependent glucose transporter GLUT1, the insulin-dependent glucose transporter GLUT4, and the insulin receptor proteins, was measured in mammary tissue at the end of pregnancy, throughout lactation, and post-weaning (Manjarín et al., 2012a). Relative abundance of all 3 genes was relatively high across all stages, with GLUT1 being two-fold greater than GLUT4 and insulin receptor, with no change in expression occurring between early and peak lactation. Both GLUT1 and GLUT4 are high capacity, low affinity and high Km transporter proteins, and as such, monosaccharide uptake by the mammary gland would be expected to increase with an increase in arterial glucose concentrations. This is not surprising given the importance of glucose as a substrate for lactose synthesis in sow milk. Renaudeau et al. (2003) estimated that 1,300 g of glucose was needed to support a milk yield of $11 \mathrm{~kg}$. From the work of Guan et al. (2004b), it was estimated that the porcine udder removes approximately 2,000 g of glucose per day to support a daily milk yield of $11.4 \mathrm{~kg}$ (Farmer et al., 2008a). The ratio between lactose output and glucose uptake ranges from 0.35 to 0.68 across studies (Dourmad et al., 2000; Linzell et al., 1969b; Spincer et al., 1969).

\subsubsection{Uptake of other energetic precursors}

Three classic studies, namely those of Spincer et al. (1969), Linzell et al. (1969b) and Spincer and Rook (1971), have reported mammary uptake of triglycerides, phospholipids, acetate, propionate and lactate in sows (Table 14.2). Other than glucose, the major sources of non-amino acid carbon uptake are triglycerides and lactate (Table 14.2). Linzell et al. (1969b) used five sows, ranging from 12 to $61 \mathrm{~d}$ of lactation to estimate mammary AVD. Lactate and triglycerides AVD were considerable whereas AVD for phospholipids, free fatty acids, volatile fatty acids and $\beta$-hydroxybutyrate were small and/or variable. Spincer et al. (1969) reported that of the total recorded mammary uptake of plasma constituents, $11 \%$ was accounted for by plasma triglycerides and only $2 \%$ by acetate. Of the plasma triglycerides, oleate (23\%), linoleate (21\%), palmitate (19\%) and stearate (16\%) were the most prominent and when radioactive triglycerides were infused intravenously, more than $60 \%$ of palmitic acid and $70 \%$ of stearic acid in milk fat were accounted for by uptake from plasma triglycerides (Spincer and Rook, 1971). Recent findings by Dourmad et al. 
Table 14.2. Arteriovenous differences $(\mathrm{mg} / 100 \mathrm{ml}$ for all variables except volatile fatty acids and free fatty acids which are in Meq/l) of plasma carbohydrates and lipids in the lactating sow (Farmer et al., 2008b).

\begin{tabular}{lccl}
\hline & Linzell et al., 1969b & Spincer et al., 1969 & Spincer and Rook, 1971 \\
Glucose & & & \\
Triglycerides & $19.8^{1}$ & 37.5 & 28.7 \\
Lactate & 7.6 & 7.2 & 10.2 \\
Phospholipids & 7.4 & 1.4 & $\mathrm{ND}$ \\
B-hydroxybutyrate & 0.3 & 4.1 & $\mathrm{ND}$ \\
Volatile fatty acids & 0.2 & 0.2 & $\mathrm{ND}$ \\
Free fatty acids & $0.2^{1,3}$ & $0.6^{4}$ & $\mathrm{ND}$ \\
Citrate & $0.1^{3}$ & $\mathrm{ND}$ & $\mathrm{ND}$ \\
\hline
\end{tabular}

${ }^{1}$ Adjusted from whole blood to plasma using the average hematocrit value of $31.7 \%$.

${ }^{2}$ Not determined.

${ }^{3}$ Both negative and positive values were observed.

${ }^{4}$ Value for acetate only.

(2000) corroborated these earlier reports on the relative uptakes of glucose, triglycerides and amino acids by the sow mammary glands.

There is some recent information on the uptake of minerals and vitamins across the mammary glands of lactating sows. Both Nielsen et al. (2002a) and Dourmad et al. (2000) showed a positive mammary AVD for calcium. Dourmad et al. (2000) also noted a positive uptake of phosphorus, with its AVD across mammary tissue increasing after a meal, whereas calcium uptake remained constant post-prandially. The extraction rates of calcium and phosphorus from arterial blood are typically lower (4.1 and 3.1\%, respectively) than that of other major nutrients (ranging from 20 to 35\%). In addition, there was very little to no uptakes of riboflavin $(3.4 \mathrm{pmol} / \mathrm{ml})$, vitamin $B(0 \mathrm{pg} / \mathrm{ml})$ or folic acid $(-1.2 \mathrm{ng} / \mathrm{ml})$ by the sow mammary glands (Dourmad et al., 2000).

\subsubsection{Uptake of energy and energetic efficiency of milk synthesis}

The uptake of energy by the mammary glands can be calculated from the uptake of glucose, amino acids and other milk precursors and their energy content. From the studies of Linzell et al. (1969b) and Renaudeau et al. (2003), energy AVD of 9.1 and 8.8 $\mathrm{kJ} / \mathrm{l}$ plasma, respectively, can be calculated (Figure 14.2). A similar value of $8.9 \mathrm{~kJ} / \mathrm{l}$ was measured in postprandial animals (Dourmad et al., 2000), whereas after $16 \mathrm{~h}$ of fasting the AVD of energy tended to decrease $(7.6 \mathrm{~kJ} / \mathrm{l})$. In fed sows, the contribution of glucose and lactate to total energy uptake by the mammary glands averaged $45 \%$, whereas in fasted sows this value dropped to $28 \%$ (Dourmad et al., 2000). The contribution of free fatty acids to energy uptake was highly dependent on nutritional status of the sows. In fasted sows, free fatty acids contributed approximately $35 \%$ of the energy uptake whereas no uptake was detected after a meal. The situation in restrictively-fed sows was 


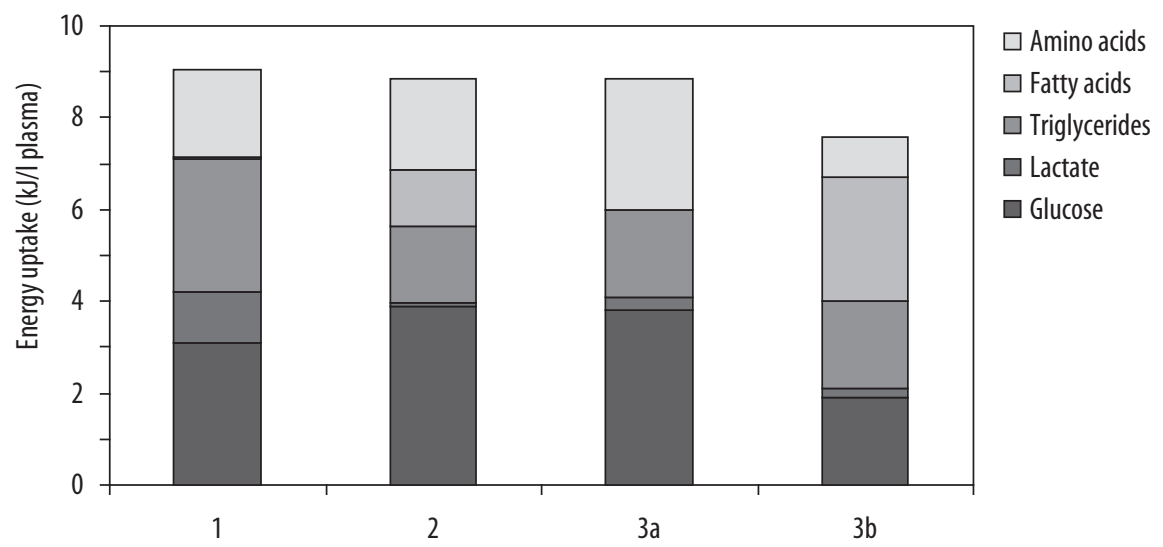

Figure 14.2. Partition of energy uptake by the mammary gland in different studies (Farmer et al., 2008b). $1=$ Linzell et al. (1969b); 2 = Renaudeau et al. (2003); $3=$ Dourmad et al. (2000). $3 a=$ post-prandial; $3 b=$ fasted.

intermediate between that of fed and fasted sows (Renaudeau et al., 2003), with free fatty acids contributing $15 \%$ of total mammary energy uptake.

The energetic efficiency of milk synthesis from plasma precursors can be calculated (Table 14.3) using mammary AVD measured by Renaudeau et al. (2003) and assuming a plasma flow of $550 \mathrm{l} / \mathrm{l}$ of milk. For a daily milk production of $10 \mathrm{~kg}$, the amount of energy present in precursors and products was 48.8 and $43.6 \mathrm{MJ} / \mathrm{d}$, respectively, corresponding to an energy efficiency of 0.89 . This value is greater than the usual estimate of ME efficiency for milk production (0.72) derived from energy metabolism studies but is very close to that reported for the efficiency of energy use from body reserves $(0.88$; Noblet and Etienne, 1987). This discrepancy between the estimates of efficiency obtained from energy metabolism studies, on one hand, and mammary balance studies, on the other hand, could be partially related to other metabolic processes associated with milk production but occurring outside the mammary gland. It may however also originate from an under-estimation of either the uptake of nutrient or blood flow. Indeed, using a biochemical model describing the stoichiometry of nutrient transformation in the mammary gland, Van Milgen et al. (2003) showed that with the data from Renaudeau et al. (2003) blood flow or AVD had to be increased by about $10 \%$ to ensure correspondence between observed and stoichiometric balances.

\subsubsection{Uptake of amino acids}

In contrast to other nutrients, the AVD and net uptake of amino acids by the sow mammary gland has been extensively measured in response to the diet (Guan et al., 2002, 2004a,b; Manjarín et al., 2012b), to stage of lactation, and to milk demand (Guan et al., 2004a,b; Nielsen et al., 2002b). Guan et al. (2004a,b) showed that net mammary uptake of amino acids increases with advancing lactation from approximately $6 \mathrm{~d}$ up to peak milk (i.e. d 14 to 18 ) demand and decreases thereafter. This increase in uptake was associated to an increase in AVD. In contrast, the increase in net amino acid uptake 
Table 14.3. Estimation of energetic efficiency of milk synthesis from precursors (Farmer et al., 2008b).

\begin{tabular}{|c|c|c|}
\hline & $g / d$ & $\mathrm{~kJ} / \mathrm{d}$ \\
\hline \multicolumn{3}{|c|}{ Precursors (uptake for $10 \mathrm{I} \mathrm{milk/d)}{ }^{1}$} \\
\hline Glucose & 1,359 & 21,328 \\
\hline Lactate & 26 & 388 \\
\hline Glycerol & 246 & 9,363 \\
\hline Triglycerides & 172 & 6,714 \\
\hline Fatty acids & 8 & 149 \\
\hline Amino acids & 561 & 10,883 \\
\hline Total & 2,373 & 48,825 \\
\hline \multicolumn{3}{|c|}{ Products (output for $10 \mathrm{I}$ milk/d) $)^{2}$} \\
\hline Lactose & 560 & 8,960 \\
\hline Fat & 580 & 22,040 \\
\hline Protein & 530 & 12,561 \\
\hline Total & 1,670 & 43,561 \\
\hline Efficiency (\%) & \multicolumn{2}{|c|}{89.2} \\
\hline
\end{tabular}

1 Precursors were calculated from AVD measured by Renaudeau et al. (2002) assuming that a blood flow equivalent to 550 I plasma was required to produce $1 \mathrm{~kg}$ of milk (Trottier et al. 1997).

2 Products were estimated from Renaudeau et al. (2002).

observed with increasing litter size was associated with an increase in blood flow rather than an increase in AVD (Nielsen et al., 2002b). The change in AVD associated with day of lactation raises the question as to whether this change is related to cellular transporter protein abundance or to amino acid competitive transport inhibition. Amino acid uptake by all vertebrate cells is controlled by a coordinated activity of protein-carriers located in the cellular membrane that channel amino acids intracellularly (Broër et al., 2008; Palacín et al., 1998; Shennan et al., 2000). A review of the current knowledge on amino acid transporter proteins and their regulation in the mammary gland including that of the sow is beyond the scope of the current book chapter. Briefly, transcripts for the genes encoding for amino acid transporter proteins that fall under two sodiumdependent and two sodium-independent systems have been measured in sow mammary tissue. Of the sodium dependent systems, $\mathrm{B}^{0,+}$ and $\mathrm{y}^{+} \mathrm{L}$, the respective transcripts of the genes encoding for $\mathrm{ATB}^{0,+}, \mathrm{y}^{+} \mathrm{LAT} 1 / 4 \mathrm{~F} 2 \mathrm{hc}$ and $\mathrm{y}^{+} \mathrm{LAT} 2 / 4 \mathrm{~F} 2 \mathrm{hc}$ were reported by PérezLaspiur et al. (2009) (ATB ${ }^{0,+}$ ) and Manjarín et al. $(2011,2012 \mathrm{~b})\left(\mathrm{ATB}^{\mathrm{o},+}, \mathrm{y}^{+} \mathrm{LAT} 1 / 4 \mathrm{~F} 2 \mathrm{hc}\right.$ and $\mathrm{y}^{+} \mathrm{LAT} 2 / 4 \mathrm{~F} 2 \mathrm{hc}$ ). For the sodium independent system, $\mathrm{y}^{+}$and $\mathrm{b}^{0,+}$, the respective transcripts of their genes encoding for CAT-1, CAT-2b, and $b^{0,+}$ AT $1 /$ rBAT were also reported by Pérez-Laspiur et al. (2009) (CAT-1, CAT-2b) and Manjarín et al. (2011, 2012b) (CAT-1, CAT-2b, and $\mathrm{b}^{0,+}$ AT1).

Transcript abundance of several of these genes was shown to increase in response to milk demand (Manjarín et al., 2011), and to dietary amino acid availability (Pérez-Laspiur et al., 2009). In contrast, in the recent work by Manjarín et al. (2012b), no changes were 
found in transcript abundance of these same genes in response to dietary crude protein levels and amino acid availability. Manjarín et al. (2012b) therefore suggested that the changes in AVD of amino acids in response to dietary amino acid availability are likely a result of competitive inhibitory processes at the blood mammary cell interface rather than changes in gene expression. Continued characterization of amino acid transporter systems and their respective proteins, particularly in response to dietary and physiological challenges, will allow to better understand how milk production in sows is governed. For instance, in the study by Manjarín et al. (2011), transcript abundance of CAT-1, ATB ${ }^{0,+}$, and $y^{+}$LAT2 increased between day 112 of gestation and day 17 of lactation. Expression of these three genes was positively correlated with expression for genes encoding for $\beta$-casein and $\alpha$-lactalbumin, which are two mammary synthesized proteins. These authors (Manjarín et al., 2011) proposed that CAT-1, $\mathrm{ATB}^{0,+}$, and $\mathrm{y}^{+} \mathrm{LAT} 2$ may become molecular targets for improving sow milk production since these proteins are responsible for transport of the typically limiting amino acid lysine in the lactating sow's diet.

\subsubsection{Hormones and mammary uptake of nutrients}

Numerous hormones play a major role in the regulation of milk synthetic processes and the direct involvement of specific hormones is evidenced by the presence of their receptors in mammary tissue. Receptors for growth hormone (Manjarín et al., 2012a), IGF-I (Lee et al., 1993; Manjarín et al., 2012a; Theil et al., 2006), leptin (Palin et al., 2004), prolactin (Manjarín et al., 2012a; Palin et al., 2004; Plaut et al., 1989; Theil et al., 2005; Trott et al., 2009), insulin (Manjarín et al., 2012a), glucocorticoids (Manjarín et al., 2012a), and oxytocin (Lundin-Schiller et al., 1996) are present in porcine mammary tissue. These receptors are under complex regulation, which will not be discussed because it is beyond the scope of the present chapter.

There is a scarcity of information on the role of lactogenic hormones in the regulation of mammary nutrient uptake during lactation in swine. Pettigrew et al. (1993) showed that circulating insulin concentrations were related to protein $(\mathrm{r}=0.42)$, fat $(\mathrm{r}=0.39)$ and lactose $(\mathrm{r}=0.36)$ contents in milk, thereby indicating that insulin may be involved in uptake of plasma substrates by the mammary gland during lactation. The transcript of the gene encoding for the insulin receptor protein is relatively abundant in porcine mammary tissue and remains invariant between the end of gestation, throughout lactation and postweaning (Manjarín et al., 2012a).

An in vitro study showed that exogenous insulin, in combination with prolactin and cortisol, can lead to significant increases in rates of lipid synthesis and glucose oxidation by porcine mammary explants (Jerry et al., 1989). Furthermore, a close relationship between concentrations of prolactin and rate of glucose metabolism in porcine mammary tissue was reported (Jerry et al., 1989) and prolactin binding to its receptor on sow mammary tissue was postulated as being a major effector of mammary metabolic rate (Plaut et al., 1989). Such an involvement of prolactin in nutrient metabolism within mammary tissue would not be surprising in light of its essential role for both the initiation and the maintenance of lactation in sows (Farmer et al., 1998). 
An in vivo study showed that when sows were fed different levels of crude protein, arterial insulin and prolactin concentrations were strongly correlated with mammary amino acid AVD, thereby providing evidence of a link between insulin and prolactin concentrations and amino acid uptake by the mammary gland. It may therefore be that amino acid utilization by the sow mammary gland could be regulated via circulating concentrations of insulin and prolactin binding to porcine mammary cells (Farmer et al., 2008). The mRNA abundance, however, for the prolactin receptor encoding gene in sow mammary tissue was greater on $\mathrm{d} 17$ than on $\mathrm{d} 5$ of lactation, but was not correlated to the expression of genes encoding the milk proteins $\alpha$-lactalbumin and $\beta$-casein (Manjarín et al., 2012a). A recent study also showed that increasing circulating concentrations of prolactin in late gestation led to greater piglet growth rate, and also augmented the postpartum increase in mRNA expression of genes encoding for $\beta$-casein, $\alpha$-lactalbumin and glucose transporter 1 (VanKlompenberg et al., 2013). In the study by Farmer et al. (2008) however glucose AVD was poorly correlated with circulating concentrations of prolactin. In that same study, glucose AVD was also poorly correlated with circulating concentrations of insulin. The extent of insulin dependence for glucose transport across the porcine mammary gland is unknown. The bulk of glucose transport is likely mediated via an insulin independent glucose transporter. As mentioned earlier, transcript for the genes encoding GLUT1, an insulin independent glucose transporter was twice as abundant as that of GLUT4, the insulin dependent glucose transporter. Furthermore, transport per se of neither glucose nor amino acids appeared to be under IGF-I regulation (Farmer et al., 2008). Transgenic sows over-expressing mammary IGF-I also had similar milk composition than control sows (Monaco et al., 2005), further suggesting little role of IGF-I on nutrient uptake by mammary tissue.

Finally, there is little information on the role of glucocorticoids in sows. In one study, the expression of the gene encoding for the glucocorticoid receptor during the prepartum until the post-weaning period was positively correlated with expression of $\alpha$-lactalbumin and $\beta$-casein (Manjarín et al., 2012a), indicating a likely role in amino acid uptake.

\subsection{Conclusions}

The amount of milk produced by lactating sows is ultimately dependent on the availability of nutrients to the mammary gland (Boyd et al., 1995). This availability is in turn affected by mammary blood flow and nutrient uptake. Estimation of mammary blood flow is quite sophisticated and requires catheterization of blood vessels. Most reported plasma flow values range between 1.9 and $4.9 \mathrm{l} / \mathrm{min}$, and the one major factor involved in modulating mammary blood flow is milk removal. Studies based on mammary AVD showed that there is major uptake of glucose and amino acids by the sow mammary gland and, to a lesser extent, there is also uptake of other energetic precursors such as triglycerides, phospholipids, acetate, propionate and lactate. Nutrient uptake by the sow udder is largely regulation by the diet and is also affected by factors such as stage of lactation and nursing intensity. In the case of glucose and amino acids, there are transporters located on the mammary glands that are needed for their uptake, yet the nutritional and molecular regulations of these are not yet elucidated. It is evident that the mechanisms involved 
in controlling the processes related to milk production in sows are still not completely understood. This knowledge is essential to develop best-adapted management strategies that will optimize sow milk yield.

\section{References}

Barone, R., 1996. Anatomie comparée des mammifères domestiques. Tome cinquième angiologie, Ed. Vigot, Paris, France, pp. 372-373.

Boyd, R.D., Kensinger, R.S., Harrell, R.J. and Bauman, D.E., 1995. Nutrient uptake and endocrine regulation of milk synthesis by mammary tissue of lactating sows. Journal of Animal Science 73(2): 36-56.

Broër, S., 2008. Amino acid transport across mammalian intestinal and renal epithelia. Physiological Reviews 88: 249-286.

Busk, H., Sorensen, M.T., Mikkelsen, E.O., Nielsen, M.O. and Jakobsen, K., 1999. Responses to potential vasoactive substances of isolated mammary blood vessels from lactating sows. Comparative Biochemistry and Physiology Part C: Toxicology \& Pharmacology 124: 57-64.

Dourmad, J.Y., Matte, J.J., Lebreton, Y. and Fontin, M.L., 2000. Influence du repas sur l'utilisation des nutriments et des vitamines par la mamelle chez la truie en lactation. Journées de Recherche Porcine en France 32: 265-273.

Eriksson, M., Lind, B., Uvnas-Moberg, K. and Hokfelt, T., 1996. Distribution and origin of peptidecontaining nerve fibres in the rat and human mammary gland. Neuroscience 70: 227-245.

Farmer, C., Guan, X. and Trottier, N.L., 2008a. Mammary arteriovenous differences of glucose, insulin, prolactin and IGF-I in lactating sows under different protein intake levels. Domestic Animal Endocrinology 34: 54-62.

Farmer, C. and Hurley, W.L., 2015. Mammary development. Chapter 4. In: Farmer, C. (ed.) The gestating and lactating sow. Wageningen Academic Publishers, Wageningen, the Netherlands, pp. 73-94.

Farmer, C., Robert, S and Rushen, J., 1998. Bromocriptine given orally to periparturient sows inhibits milk production. Journal of Animal Science 76: 750-757.

Farmer, C., Trottier, N.L. and Dourmad, J.Y., 2008b. Review: current knowledge on mammary blood flow, mammary uptake of energetic precursors and their effects on sow milk yield. Canadian Journal of Animal Science 88: 195-204.

Fick, A., 1870. Ueber die Messung des Blutquantums in den Herzventrikeln. PhysikalischMedizinische Gesellschaft zu Wiirzburg 2: 16-28.

Franke-Radowiecka, A. and Wasowicz, K., 2002. Adrenergic and cholinergic innervation of the mammary gland in the pig. Anatomy Histology and Embryology 31: 3-7.

Ghoshal, N.G., 1975. Porcine heart and arteries. In: Sisson, S., Grossman, J.D. and Getty, R. (eds.) The anatomy of the Domestic Animals, volume 2. W.B. Saunders Company, Philadelphia, PA, USA, pp. 1306-1342.

Guan, X., Bequette, B.J., Calder, G., Ku, P.K., Ames, K.N. and Trottier, N.L., 2002. Amino acid availability affects amino acid transport and protein metabolism in the porcine mammary gland. Journal of Nutrition 132: 1224-1234.

Guan, X., Bequette, B.J., Ku, P.K., Tempelman, R.J. and Trottier, N.L., 2004a. The amino acid need for milk synthesis is defined by the maximal uptake of plasma amino acids by porcine mammary glands. Journal of Nutrition 134: 2182-2190. 
Guan, X., Pettigrew, J.E., Ku, P.K., Ames, N.K., Bequette, B.J. and Trottier, N.L., 2004b. Dietary protein concentration affects plasma arterio-venous difference of amino acids across the porcine mammary gland. Journal of Animal Science 82: 2953-2963.

Jerry, J., Stover, R.K. and Kensinger, R.S., 1989. Quantitation of prolactin-dependent responses in porcine mammary explants. Journal of Animal Science 67: 1013-1019.

Kent, J.C., Kennaugh, L.M. and Hartmann, P., 2003. Intramammary pressure in the lactating sow in response to oxytocin and during natural milk ejections throughout lactation. Journal of Dairy Research 70: 131-138.

Kety, S.S. and Schmidt, C.F., 1945. The determination of cerebral blood flow in man by the use of nitrous oxide in low concentrations. American Journal of Physiology 143: 53-66.

Kim, S.W., Easter, R.A. and Hurley, W.L., 2001. The regression of unsuckled mammary glands during lactation in sows: the influence of lactation stage, dietary nutrients, and litter size. Journal of Animal Science 79: 2659-2668.

Klindt, J., 2003. Influence of litter size and creep feeding on preweaning gain and influence of preweaning growth on growth to slaughter in barrows. Journal of Animal Science 81: 2434-2439.

Klopfenstein, C., Farmer, C. and Martineau, G.P., 2006. Diseases of the mammary glands. In: Straw, B.E., Zimmerman, J.J., D’Allaire, S. and Taylor, D.J. (eds.) Diseases of swine, $9^{\text {th }}$ edition. Blackwell Publishing, Oxford, UK, pp. 57-85.

Lacasse, P., Farr, V.C., Davis, S.R. and Prosser, C.G., 1996. Local secretion of nitric oxide and the control of mammary blood flow. Journal of Dairy Science 79: 1369-1374.

Lapierre, H., Doepel, L., Milne, E. and Lobley, G.E., 2009. Responses in mammary and splanchnic metabolism to altered lysine supply in dairy cows. Animal 3: 360-371.

Lee, C.Y., Bazer, F.W. and Simmen, F.A., 1993. Expression of components of the insulin-like growth factor system in pig mammary glands and serum during pregnancy and pseudopregnancy: effects of oestrogen. Journal of Endocrinology 137: 473-483.

Lignereux, Y., Rossel, R. and Jouglard, J.Y., 1996. Note sur la vascularisation veineuse des mamelles chez la truie. Revue de Médecine Vétérinaire 3: 191-194.

Linzell, J.L., Mephan, T.B., Annison, E.F. and West, C.E., 1969a. Mammary metabolism in lactating sows: arteriovenous differences of milk precursors of milk. In: Larson, B.L. and Smith, V.R. (eds.) Lactation, volume 1. Academic Press, New York, NY, USA, 143.

Linzell, J.L., Mephan, T.B., Annison, E.F. and West, C.E., 1969b. Mammary metabolism in lactating sows: arteriovenous differences of milk precursors and the mammary metabolism of $\left[{ }^{14} \mathrm{C}\right]$ glucose and $\left[{ }^{14} \mathrm{C}\right]$ acetate. British Journal of Nutrition 23: 319-332.

Lundin-Schiller, S., Kreider, D.L., Rorie, R,W., Haresty, D., Mitchell, M.D. and Koike, T.I., 1996. Characterization of porcine endometrial, myometrial, and mammary oxytocin binding sites during gestation and labor. Biology of Reproduction 55: 575-581.

Manjarín, R., Steibel, J.P., Kirkwood, R.N., Taylor, N.P. and Trottier, N.L. 2012a. Transcript abundance of hormone receptors, mammalian target of rapamycin pathway-related kinases, insulin-like growth factor I, and milk proteins in porcine mammary tissue. Journal of Animal Science 90: 221-230.

Manjarín, R., Steibel, J.P., Zamora, V., Am-in, N., Kirkwood, R.N., Ernst, C.W., Weber, P.S., Taylor, N.P. and Trottier, N.L., 2011. Transcript abundance of amino acid transporters, $\beta$-casein, and a-lactalbumin in mammary tissue of periparturient, lactating, and postweaned sows. Journal of Dairy Science 94: 3467-3476. 
Manjarín, R., Zamora, V., Wu, G., Steibel, J.P., Kirkwood, R.N., Taylor, N.P., Wils-Plotz, E., Trifilo, K. and Trottier, N.L., 2012b. Effect of amino acids supply in reduced crude protein diets on performance, efficiency of mammary uptake, and transporter gene expression in lactating sows. Journal of Animal Science 90: 3088-3100.

Monaco, M.H., Gronlund, D.E., Bleck, G.T., Hurley, W.L., Wheeler, M.B. and Donovan, S.M., 2005. Mammary specific transgenic over-expression of insulin-like growth factor-I (IGF-I) increases pig milk IGF-I and IGF binding proteins, with no effect on milk composition or yield. Transgenic Research 14: 761-773.

National Research Council (NRC), 2012. Nutrient requirements of swine, $11^{\text {th }}$ revised edition. National Research Council of the National Academies. Washington, DC, USA.

Nielsen, T.T., Pierzynowski, S.G., Borsting C.F., Nielsen, M.O. and Jakobsen, K., 2002a. Catheterization of arteria epigastrica cranialis, measurement of nutrient arteriovenous differences and evaluation of daily plasma flow across the mammary gland of lactating sows. Acta Agricultura Scandinavia Section A: Animal Science 42: 113-120.

Nielsen, T.T., Trottier, N.L., Stein, H.H., Bellavers, C. and Easter, R.A., 2002b. The effect of litter size and day of lactation on amino acid uptake by the porcine mammary glands. Journal of Animal Science 80: 2402-2411.

Noblet, J. and Etienne, M., 1987. Metabolic utilisation of energy and maintenance requirements of lactating sows. Journal of Animal Science 64: 774-781.

Olsson, K., Malmgren, C., Olsson, K.K., Hansson, K. and Häggström, J., 2003. Vasopressin increases milk flow and milk fat concentration in the goat. Acta Physiologica Scandinavia 177: 177-184.

Palacin, M., Estevez, R., Bertran, J. and Zorzano, A., 1998. Molecular biology of mammalian amino acid transporters. Physiological Reviews 78: 969-1054.

Palin, M.F., Beaudry, D. and Farmer, C., 2004. Gene expression of leptin, leptin receptor, prolactin receptor and whey acidic protein in mammary glands of late-pregnant gilts from two breeds. Canadian Journal of Animal Science 84: 621-629.

Pérez Laspiur, J., Burton, J.L., Weber, P.S.D., Moore, J., Kirkwood, R.N. and Trottier, N.L., 2009. Dietary protein intake and stage of lactation differentially modulate amino acid transporter mRNA abundance in porcine mammary tissue. Journal of Nutrition 139: 1677-1684.

Pettigrew, J.E., McNamara, J.O., Tokach, M.D., King, R.H. and Crooker, B.A., 1993. Metabolic connections between nutrient intake and lactational performance in the sow. Livestock Production Science 35: 137-152.

Plaut, K.I., Kensinger, R.S., Griel, Jr., L.C. and Kavanaugh, J.F., 1989. Relationships among prolactin binding, prolactin concentrations in plasma and metabolic activity of the porcine mammary gland. Journal of Animal Science 67: 1509-1519.

Renaudeau, D., Lebreton, Y., Noblet, J. and Dourmad, J.Y., 2002. Measurement of blood flow through the mammary gland in lactating sows: methodological aspects. Journal of Animal Science 80: 196-201.

Renaudeau, D., Noblet, J. and Dourmad, J.Y., 2003. Effect of ambient temperature on mammary gland metabolism in lactating sows. Journal of Animal Science 81: 217-231.

Schummer, A., Wilkens, H., Vollmerhaus, B. and Habermehl, K.H., 1981. Skin and cutaneous organs. In: Nickel, R., Schummer, A. and Seiferle, E. (eds.) The anatomy of the domestic animals,. volume 3 . The circulatory system, the skin, and the cutaneous organs of the domestic mammals. Springer-Verlag, New York, NY, USA, pp. 473-557. 
Shennan, D.B. and Peaker, M., 2000. Transport of milk constituents by the mammary gland. Physiological Reviews 80: 925-951.

Spincer, J. and Rook, J.A.F., 1971. The metabolism of $\left[\mathrm{U}-{ }^{14} \mathrm{C}\right]$ glucose, $\left[1-{ }^{14} \mathrm{C}\right]$ palmitic acid and $\left[1-{ }^{14} \mathrm{C}\right]$ stearic acid by the lactating mammary gland of the sow. Journal of Dairy Research 38: 315-322.

Spincer, J., Rook, J.A.F. and Towers, K.G., 1969. The uptake of plasma constituents by the mammary gland of the sow. Biochemistry Journal 111: 727-732.

Theil, P.K., 2015. Transition feeding of sows. Chapter 7. In: Farmer, C. (ed.) The gestating and lactating sow. Wageningen Academic Publishers, Wageningen, the Netherlands, pp. 147-172.

Theil, P.K., Labouriau, R., Sejrsen, K., Thomsen, B. and Sorensen, M.T., 2005. Expression of genes involved in regulation of cell turnover during milk stasis and lactation rescue in sow mammary glands. Journal of Animal Science 83: 2349-2356.

Theil, P.K., Sejrsen, K., Hurley, W.L., Labouriau, R., Thomsen, B. and Sorensen, M.T., 2006. Role of suckling in regulating cell turnover and onset and maintenance of lactation in individual mammary glands of sows. Journal of Animal Science 84: 1691-1698.

Trott, J.F., Horigan, K.C., Gloviczki, J.M., Costa, K.M., Freking, B.A., Farmer, C., Hayashi, K., Spencer, T., Morabito, J.E. and Hovey, R.C., 2009. Tissue-specific regulation of porcine prolactin receptor expression by estrogen, progesterone and prolactin. Journal of Endocrinology 202: 153-166.

Trottier, N.L., Shipley, C.F. and Easter, R.A., 1995a. A technique for the venous cannulation of the mammary gland in the lactating sow. Journal of Animal Science 73: 1390-1395.

Trottier, N.L., Shipley, C.F. and Easter, R.A., 1995b. Arteriovenous differences for amino acids, urea nitrogen, ammonia, and glucose across the mammary gland of the lactating sow. Journal of Animal Science 73(2): 57-58.

Trottier, N.L., Shipley, C.F. and Easter, R.A., 1997. Plasma amino acid uptake by the mammary gland of the lactating sow. Journal of Animal Science 75: 1266-1278.

Turner, C.W., 1952. The anatomy of the mammary gland of swine. In: The mammary gland. I. The anatomy of the udder of cattle and domestic animals. Lucas Brothers, Columbia, MO, USA, pp. 279-314.

Van Milgen, J., Gondret, F. and Renaudeau, D., 2003. The use of nutritional models as a tool in basic research. In: Souffrant, W.B. and Metges, C.C. (eds.) Progress in research on energy and protein metabolism. European Federation of Animal Science (EAAP) publication no. 109, pp. 259-263.

VanKlompenberg, M.K., Manjarín, R., Trot, J.F., McMicking, H.F. and Hovey, R.C., 2013. Lategestational hyperprolactinemia accelerates mammary epithelial cell differentiation that leads to increased milk yield. Journal of Animal Science 91: 1102-1111. 